\title{
Reference equations for parameters of impulse oscillometry in Egyptian children and adolescents
}

\author{
Sally Raafat Ishak ${ }^{1 *}$ and Azza Mohammed Hassan²
}

\begin{abstract}
Background: Impulse oscillometry (IOS) is important in diagnosing respiratory functions in non-cooperative children. Studies are rising nowadays to establish reliable reference values of IOS for children of different ethnicities. No available data about the regression equations for parameters of IOS for Egyptian children and adolescents. So, our study aimed to develop regression equations for parameters of IOS in Egyptian children and adolescents in relation to their age, weight, height, and body mass index.

Results: Height and age affected the regression equation of impedance at $5 \mathrm{~Hz}(\mathrm{Z} 5 \mathrm{~Hz})$ and resistance at $5 \mathrm{~Hz}(\mathrm{R} 5 \mathrm{~Hz})$ in both males and females, resistance at $20 \mathrm{~Hz}(\mathrm{R} 20 \mathrm{~Hz})$ in males and reactance at $5 \mathrm{~Hz}(\mathrm{X} 5 \mathrm{~Hz})$ in females. Height affected the regression equation of $\mathrm{R} 20 \mathrm{~Hz}$ in females, resonant frequency (Fres) in males, and the area of reactance (AX) in both males and females. While age affected the equation of $\mathrm{X} 5 \mathrm{~Hz}$ in males and Fres in males.
\end{abstract}

Conclusions: Height and age were the most predictive values affecting the regression equation of IOS in Egyptian children and adolescents.

Keywords: Reference equation, Egypt, Impulse oscillometry, Pulmonary functions

\section{Background}

Pulmonary function tests are important tools in the diagnosis and follow-up of different respiratory diseases especially chronic lung diseases [1].

The impulse oscillometry system (IOS) is important in the diagnosis of respiratory functions in non-cooperative children [2]. It does not depend on the effort of the patients as it needs only tidal breathing, then the sound waves emitted by the apparatus are superimposed on normal tidal breathing, and the disturbances in the flow and pressure (caused by the external waves done by the patients) are used to calculate the resistance to airflow and the reactive parameters over a wide range of frequencies (usually from 5 to $20 \mathrm{~Hz}$ ). Both the airway resistance and reactance determines the impedance $[3,4]$.
The best results of IOS done by the patients are usually compared to the predictive reference value of the same sex, age, weight, height, body mass index (BMI) of the patients. These reference values are different for children of different ethnicities; therefore, studies aim to develop local reference values [5]. Studies are increasing nowadays in different populations to increase the use of IOS and its reliability especially in non-cooperative children because till now spirometry is used more reliably as it is more studied [6].

No available predicted values of IOS for Egyptian children and adolescents. The purpose of this study was to get a reliable regression equation for Z $25 \mathrm{~Hz}, \mathrm{R} 5 \mathrm{~Hz}, \mathrm{R} 20$ $\mathrm{Hz}, \mathrm{X} 5 \mathrm{~Hz}$, Fres, and AX according to age, sex, weight, and height for Egyptian children and adolescents.

\footnotetext{
* Correspondence: Sally.raafat@med.asu.edu.eg

${ }^{1}$ Pediatric Department, Faculty of Medicine, Ain Shams University, Cairo

11865, Egypt

Full list of author information is available at the end of the article
}

\section{Springer Open}

(c) The Author(s). 2020 Open Access This article is licensed under a Creative Commons Attribution 4.0 International License, which permits use, sharing, adaptation, distribution and reproduction in any medium or format, as long as you give appropriate credit to the original author(s) and the source, provide a link to the Creative Commons licence, and indicate if changes were made. The images or other third party material in this article are included in the article's Creative Commons licence, unless indicated otherwise in a credit line to the material. If material is not included in the article's Creative Commons licence and your intended use is not permitted by statutory regulation or exceeds the permitted use, you will need to obtain permission directly from the copyright holder. To view a copy of this licence, visit http://creativecommons.org/licenses/by/4.0/. 


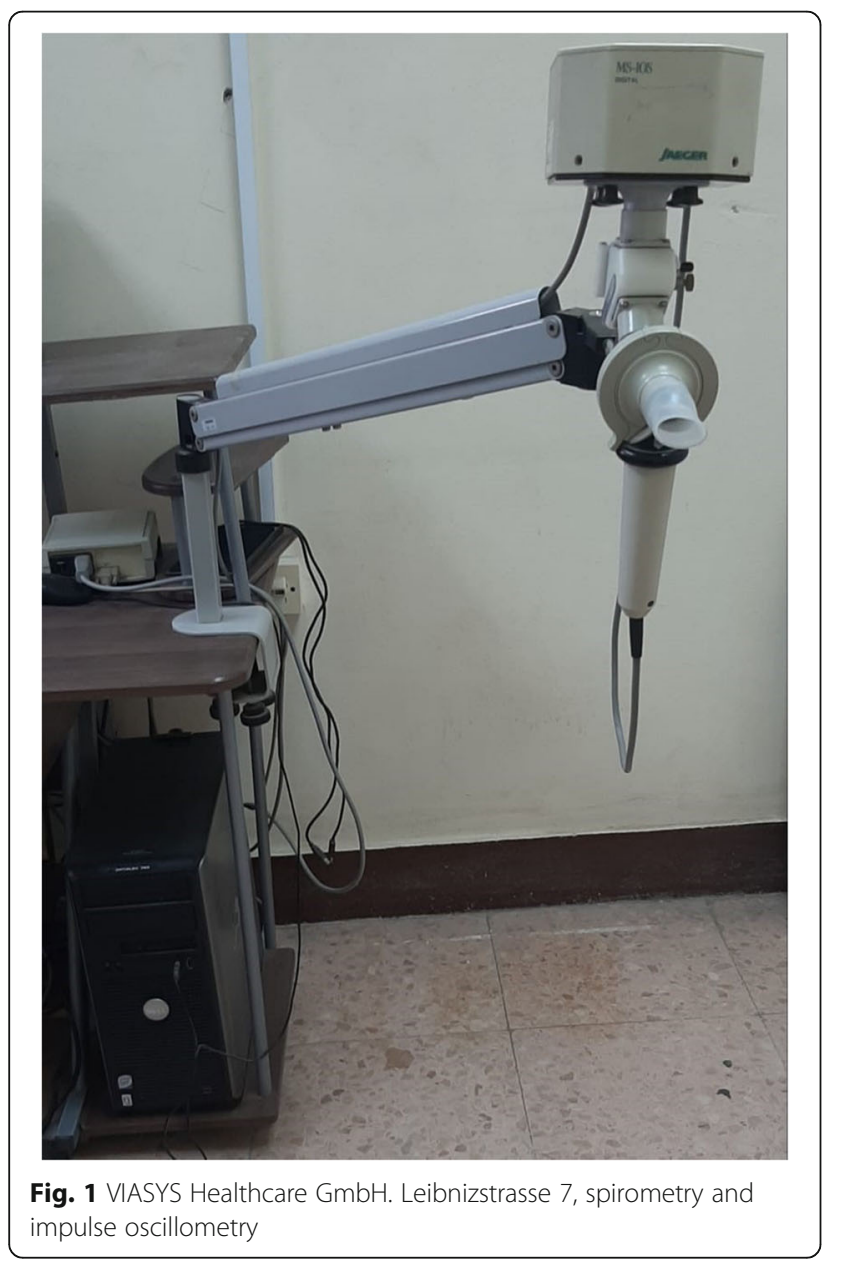

\section{Methods}

One hundred thirteen children were able to perform the maneuver properly to get reliable results. They were 65 males and 48 females, their age ranging from 3 to 18 years with a mean of $9.97 \pm 4.21$ years.

Table 1 Description of anthropometric characteristics and parameters of IOS of studied patients ( $n=113$ )

\begin{tabular}{|c|c|c|c|c|}
\hline & Minimum & Maximum & Mean & SD \\
\hline Weight (kg) & 12.00 & 62.00 & 26.62 & 12.18 \\
\hline Height (cm) & 64.00 & 168.00 & 120.92 & 19.88 \\
\hline BMI $\left(\mathrm{kg} / \mathrm{m}^{2}\right)$ & 11.60 & 27.2 & 17.25 & 3.38 \\
\hline Fres (Kpascal) & 4.50 & 32.70 & 21.47 & 5.23 \\
\hline AX (Kpascal) & 0.17 & 6.63 & 2.42 & 1.40 \\
\hline R5 Hz (Kpascal) & 0.24 & 1.37 & 0.80 & 0.25 \\
\hline R20 Hz (Kpascal) & 0.24 & 1.01 & 0.56 & 0.18 \\
\hline X5 Hz (Kpascal) & -0.71 & 0.34 & -0.30 & 0.15 \\
\hline Z5 Hz (Kpascal) & 0.28 & 1.51 & 0.86 & 0.27 \\
\hline
\end{tabular}

$Z 5 \mathrm{~Hz}$ impedance at $5 \mathrm{~Hz}, R 5 \mathrm{~Hz}$ resistance at $5 \mathrm{~Hz}, R 20 \mathrm{~Hz}$ resistance at $20 \mathrm{~Hz}$, $X 5 \mathrm{~Hz}$ reactance at $5 \mathrm{~Hz}$, Fres resonant frequency, $A X$ area of reactance
Table 2 Comparison between boys and girls regarding age, anthropometric measures, and IOS parameters

\begin{tabular}{|c|c|c|c|c|c|c|}
\hline & \multicolumn{2}{|l|}{ Boys } & \multicolumn{2}{|l|}{ Girls } & \multirow[t]{2}{*}{$t^{\mathrm{a}}$} & \multirow{2}{*}{$\begin{array}{l}P \\
\text { value }\end{array}$} \\
\hline & Mean & SD & Mean & SD & & \\
\hline Age (years) & 10.49 & 4.31 & 9.27 & 4.00 & 1.535 & 0.128 \\
\hline Weight (kg) & 27.02 & 11.23 & 26.08 & 13.47 & 0.400 & 0.690 \\
\hline Height (cm) & 122.78 & 19.95 & 118.40 & 19.71 & 1.162 & 0.248 \\
\hline BMI $\left(\mathrm{kg} / \mathrm{m}^{2}\right)$ & 19.62 & 17.78 & 17.87 & 5.05 & 0.663 & 0.509 \\
\hline Fres (Kpascal) & 21.23 & 4.51 & 21.79 & 6.11 & 0.555 & 0.580 \\
\hline AX (Kpascal) & 2.24 & 1.26 & 2.66 & 1.54 & 1.612 & 0.110 \\
\hline R5 Hz (Kpascal) & 0.76 & 0.24 & 0.84 & 0.25 & 1.662 & 0.099 \\
\hline R20 Hz (Kpascal) & 0.53 & 0.16 & 0.60 & 0.19 & 1.975 & 0.051 \\
\hline X5 Hz (Kpascal) & -0.28 & 0.16 & -0.34 & 0.14 & 2.175 & $0.032+$ \\
\hline Z5 Hz (Kpascal) & 0.82 & 0.27 & 0.91 & 0.28 & 1.800 & 0.075 \\
\hline
\end{tabular}

${ }^{a}$ Student's $t$ test

${ }^{\dagger} P$ value is significant at 0.05 level

Exclusion criteria: any patient with acute or chronic chest disease, on recent or previous respiratory medication, allergic rhinitis or acute and chronic rhinosinusitis, obese children; or children with neurological or muscular diseases.

\section{Sample size justification}

Using $\mathrm{G}$ power software for sample size calculation, using the $F$ test for linear multiple regression, fixed model, $R^{2}$ deviation from zero.

Setting alpha error at 0.05 , power at 0.95 , medium effect size $(0.15)$ for regression equation with two predictors, a sample size of at least 110 persons are needed.

Data of the patients were collected as age, sex, weight, height, and body mass index (BMI).

Table $\mathbf{3}$ Correlation between IOS parameters and both age and anthropometric measures among boys

\begin{tabular}{|c|c|c|c|c|c|}
\hline & & $\begin{array}{l}\text { Age } \\
\text { (years) }\end{array}$ & $\begin{array}{l}\text { Weight } \\
\text { (kg) }\end{array}$ & $\begin{array}{l}\text { Height } \\
\text { (cm) }\end{array}$ & $\begin{array}{l}\text { BMI } \\
\left(\mathrm{kg} / \mathrm{m}^{2)}\right.\end{array}$ \\
\hline \multirow[t]{2}{*}{ Fres } & $r^{a}$ & -0.502 & -0.252 & -0.214 & 0.007 \\
\hline & $P$ value & $<0.001 \neq$ & $0.043 \dagger$ & 0.087 & 0.955 \\
\hline \multirow[t]{2}{*}{$A X$} & $r$ & -0.709 & -0.478 & -0.583 & 0.030 \\
\hline & $P$ value & $<0.001 \neq$ & $<0.001 \neq$ & $<0.001 \neq$ & 0.815 \\
\hline \multirow[t]{2}{*}{ R5 Hz } & $r$ & -0.671 & -0.565 & -0.678 & 0.023 \\
\hline & $P$ value & $<0.001 \neq$ & $<0.001 \neq$ & $<0.001 \neq$ & 0.854 \\
\hline \multirow[t]{2}{*}{$\mathrm{R} 20 \mathrm{~Hz}$} & $r$ & -0.573 & -0.551 & -0.613 & 0.018 \\
\hline & $P$ value & $<0.001 \neq$ & $<0.001 \neq$ & $<0.001 \neq$ & 0.887 \\
\hline \multirow[t]{2}{*}{$\mathrm{X} 5 \mathrm{~Hz}$} & $r$ & 0.632 & 0.490 & 0.563 & -0.091 \\
\hline & $P$ value & $<0.001 \neq$ & $<0.001 \neq$ & $<0.001 \neq$ & 0.472 \\
\hline \multirow[t]{2}{*}{$\mathrm{Z} 5 \mathrm{~Hz}$} & $r$ & -0.702 & -0.593 & -0.700 & 0.036 \\
\hline & $P$ value & $<0.001 \neq$ & $<0.001 \neq$ & $<0.001 \neq$ & 0.777 \\
\hline
\end{tabular}

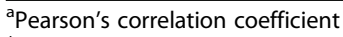

${ }^{\dagger}$ Significant at 0.05 level

${ }^{\ddagger}$ Highly significant at 0.01 level 

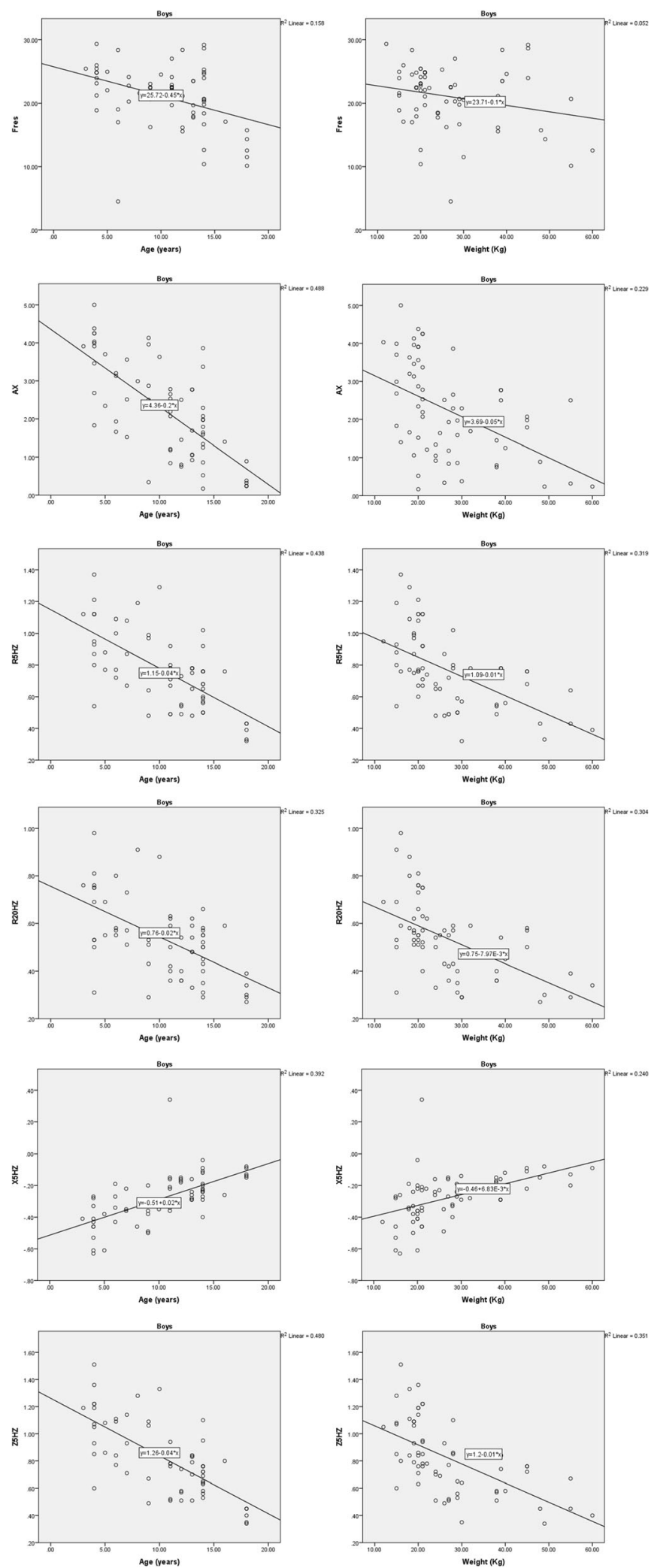

Fig. 2 Regression curve for weight and age in males 
Table 4 Correlation between IOS parameters and both age and anthropometric measures among girls

\begin{tabular}{|c|c|c|c|c|c|}
\hline & & $\begin{array}{l}\text { Age } \\
\text { (years) }\end{array}$ & $\begin{array}{l}\text { Weight } \\
(\mathrm{kg})\end{array}$ & $\begin{array}{l}\text { Height } \\
\text { (cm) }\end{array}$ & $\begin{array}{l}\text { BMI } \\
\left(\mathrm{kg} / \mathrm{m}^{2)}\right.\end{array}$ \\
\hline \multirow[t]{2}{*}{ Fres } & $r^{a}$ & -0.284 & -0.391 & -0.372 & -0.175 \\
\hline & $P$ value & $0.050+$ & $0.006 \neq$ & $0.009 \neq$ & 0.233 \\
\hline \multirow[t]{2}{*}{$A X$} & $r$ & -0.501 & -0.474 & -0.525 & -0.108 \\
\hline & $P$ value & $<0.001 \neq$ & $0.001 \neq$ & $<0.001 \neq$ & 0.465 \\
\hline \multirow[t]{2}{*}{ R5 Hz } & $r$ & -0.584 & -0.621 & -0.658 & -0.236 \\
\hline & $P$ value & $<0.001 \neq$ & $<0.001 \neq$ & $<0.001 \neq$ & 0.106 \\
\hline \multirow[t]{2}{*}{$\mathrm{R} 20 \mathrm{~Hz}$} & $r$ & -0.457 & -0.516 & -0.467 & -0.307 \\
\hline & $P$ value & $0.001 \neq$ & $<0.001 \neq$ & $0.001 \neq$ & $0.034 \dagger$ \\
\hline \multirow[t]{2}{*}{ X5 Hz } & $r$ & 0.591 & 0.590 & 0.620 & 0.147 \\
\hline & $P$ value & $<0.001 \neq$ & $<0.001 \neq$ & $<0.001 \neq$ & 0.318 \\
\hline \multirow[t]{2}{*}{ Z5 Hz } & $r$ & -0.603 & -0.638 & -0.676 & -0.225 \\
\hline & $P$ value & $<0.001 \neq$ & $<0.001 \neq$ & $<0.001 \neq$ & 0.124 \\
\hline
\end{tabular}

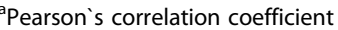

${ }^{\dagger}$ Significant at 0.05 level

${ }^{\text {F}}$ Significant at 0.01 level

The impulse oscillometry procedure was done by all children using VIASYS Healthcare GmbH. Leibnizstrasse 7, Jaeggar, Germany (Fig. 1), according to the American Thoracic Society and European Respiratory Society (ATS/ ERS) recommendations [7]:

1. We calibrate the apparatus.

2. Insert patient personal data (name, sex, birth date, weight, and height).

3. Steps were explained to the child for the best performance of the test.

4. The child was asked to sit down in a comfortable chair.

5. A nasal clip was applied to the patient who was asked to mouth breath through a sterile mouthpiece that was grasped tightly by his/her lips and the tongue did not occlude it.

6. On switching on IOS, a small loudspeaker creates a pulse-shaped pressure wave in front of the mouth, with alternate pulses (at different cycles per second [i.e., $5 \mathrm{~Hz}, 10 \mathrm{~Hz}, 20 \mathrm{~Hz}, 25 \mathrm{~Hz}$ ]).

7. The patient was asked to take tidal breathing with his cheeks supported by the hands of the investigator or the caregiver.

8. Z5 Hz, R5 Hz, R20 Hz, X5 Hz, Fres, and AX were calculated by the software of the apparatus.

Each patient performed 3 trials with less than 10\% variabilities. The time of the regular breathing pattern was 90 s. The impedance-time curve was monitored during the measurement to detect possible signs of artifacts.

Accepted patients did the technique properly, with coherence at least 0.8 at $5 \mathrm{~Hz}$ and 0.9 at $20 \mathrm{~Hz}$
The study was approved by the local ethics committee of Children's Hospital, Faculty of Medicine, Ain Shams University.

Written consent was taken from the caregiver of the children and adolescents who participated in the study.

\section{Statistical analysis}

Analysis of data was done using SPSS program version 23. Quantitative variables are presented as mean and SD, qualitative variables presented as count and percentage. The Student $t$ test was used to compare different quantitative variables between boys and girls. Pearson's correlation was used to measure the correlation between IOS parameters and other variables.

Multivariate models were developed by multiple linear regression, incorporating predictor variables correlated to the dependent variable. To choose the best model, the coefficient of determination (adjusted $R^{2}$ ) was used. The significance level was set at 5\% $(P$ value $<0.05)$; and highly significant at $1 \%(P$ value $<0.01)$.

\section{Results}

From a total of 113 children who participated in the study, 65 were boys (57.5\%) and 48 were girls (42.5\%). Their age ranged from 3 to 18 years with a mean of $9.97 \pm 4.21$ years. Table 1 shows the description of their anthropometric measures and IOS parameters. No significant difference was found between boys and girls regarding age, anthropometric measures, and IOS parameters except for R20 Hz, X5 $\mathrm{Hz}$, and $\mathrm{Z} 5 \mathrm{~Hz}$ ( $P$ value $\leq 0.05$ ) (Table 2 ).

Table 3 and Fig. 2 shows a correlation between different IOS parameters and both age and anthropometric measures among studied boys. There was a statistically significant negative correlation between all IOS parameters and both age and weight except for $\mathrm{X} 5 \mathrm{~Hz}$ where the correlation was positive $(P$ value $<0.05)$. There was also a statistically significant negative correlation between IOS parameters (AX, R5 Hz, R20 Hz, and Z5 Hz) and height and a significant positive correlation between X5 $\mathrm{Hz}$ and height $(P$ value $<0.05)$.

Regarding the correlation between different IOS parameters and both age and anthropometric measures among girls, (Table 4 and Fig. 3) shows that there was a statistically significant negative correlation between all IOS parameters and both age and weight except for X $5 \mathrm{~Hz}$ where the correlation was positive $(P$ value $<0.05)$. There was also a statistically significant negative correlation between all IOS parameters and height and a significant positive correlation between X5 Hz and height $(P$ value $<0.05)$. A significant negative correlation was found also between R20 $\mathrm{Hz}$ and BMI ( $P$ value $<0.05)$. 

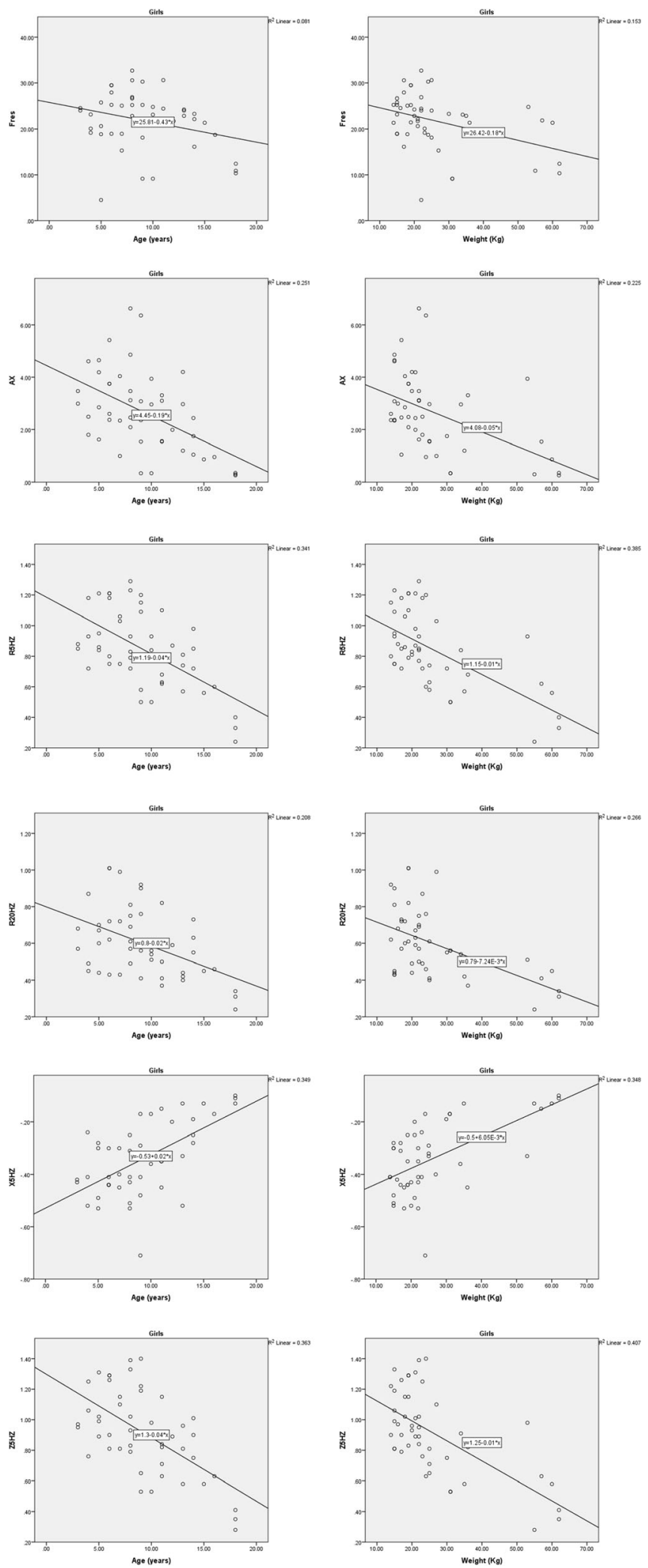

Fig. 3 Regression curves for weight and age for females 
Table 5 Respiratory system reference equations obtained by the impulse oscillometry system for boys and girls

\begin{tabular}{|c|c|c|c|c|}
\hline IOS parameters & Equations & $R^{2}, \%$ & Adjusted $R^{2}$ & SEE \\
\hline \multicolumn{5}{|l|}{ Boys: } \\
\hline Fres & $=26.742-(0.525 \times$ age $)$ & 25.2 & 24 & 3.928 \\
\hline$A X$ & $=6.778-(0.037 \times$ height $)$ & 34 & 33 & 1.035 \\
\hline $\mathrm{R} 5 \mathrm{~Hz}$ & $=1.596-(0.021 \times$ age $)-(0.005 \times$ height $)$ & 53.2 & 51.7 & 0.168 \\
\hline $\mathrm{R} 20 \mathrm{~Hz}$ & $=1.059-(0.010 \times$ age $)-(0.003 \times$ height $)$ & 41.4 & 39.5 & 0.126 \\
\hline $\mathrm{X} 5 \mathrm{~Hz}$ & $=-0.520+(0.023 \times$ age $)$ & 39.9 & 39 & 0.122 \\
\hline $\mathrm{Z} 5 \mathrm{~Hz}$ & $=1.754-(0.025 \times$ age $)-(0.005 \times$ height $)$ & 57.5 & 56.1 & 0.176 \\
\hline \multicolumn{5}{|l|}{ Girls: } \\
\hline Fres & $=35.454-(0.115 \times$ height $)$ & 13.9 & 12 & 5.731 \\
\hline$A X$ & $=7.517-(0.041 \times$ height $)$ & 27.5 & 26 & 1.325 \\
\hline $\mathrm{R} 5 \mathrm{~Hz}$ & $=1.751-(0.019 \times$ age $)-(0.006 \times$ height $)$ & 49.2 & 47 & 0.184 \\
\hline $\mathrm{R} 20 \mathrm{~Hz}$ & $=1.128-(0.004 \times$ height $)$ & 21.8 & 20.1 & 0.169 \\
\hline $\mathrm{X} 5 \mathrm{~Hz}$ & $=-0.796+(0.012 \times$ age $)+(0.003 \times$ height $)$ & 46.2 & 43.9 & 0.103 \\
\hline $\mathrm{Z} 5 \mathrm{~Hz}$ & $=1.928-(0.022 \times$ age $)-(0.007 \times$ height $)$ & 52.1 & 50 & 0.195 \\
\hline
\end{tabular}

Table 5 shows the results of multiple linear regression equations for all IOS parameters in boys and girls with their coefficients of determination $\left(R^{2}\right)$ adjusted $R^{2}$ and standard error of the estimate (SEE). Height was the variable with the most predictive power for models of all IOS parameters in girls and most of the parameters in boys.

\section{Discussion}

In our study, we found that in $\mathrm{Z} 5 \mathrm{~Hz}$ and $\mathrm{R} 5 \mathrm{~Hz}$, height and age affected the prediction equation for both males and females, while in R20 Hz, height and age affected the equation of males; but only the height affected that for females. Concerning the prediction equation for X5 Hz, age was the variable most affecting the equation in males, while height and age affected the equation in females. Height was the variable that has been shown to influence Fres in females and AX in both males and females, but the age was the variable that affected the equation of Fres in males.

So most of the predictive equations for impulse oscillometry were affected by height or age or both of them but none of the equations were affected by weight or BMI, possibly because of the association of height and age with a linear increase in lung volumes.

Comparing these with the study done on Brazilian children, height was found to be the highest predictive variable in the equations for boys in all parameters of IOS, while age had a greater influence on Fres and AX for girls [8]. Also, in a study on Mexican children and adolescents, height was the most variable influencing the equation but age also influenced the regression equation of many IOS variables, whereas body weight did not influence any regression equation; thus, reference values were made considering age and height [9]. Also, Amra et al. 2018 concluded that both height and age influenced the equation of the Iranian population [10]. While in a study on North American children, height was the only significant predictor for all variables [11].

In Poland and Swedish children, the height ${ }^{-3}$ was the most variable affecting the different oscillometric variables. But the introduction of weight helped to improve the coefficient of determination of some IOS parameters, while, factors as gender, age, and body surface area did not influence the IOS variables. Therefore, height ${ }^{-3}$ and weight were used in the regression equations done for both sex [12].

Also, studies from different ethnicities as Anglo and Hispania [13], Brazil [14], northeast Poland [15], and Taiwan [2], all showed reliability of the regression equations on the height of the children. (Table 6)

Nevertheless, both height and age affected the prediction equations of Korean and Mexican patients, although that for the Korean girls were affected by the height only $[5,9]$.

Meraz et al. 2007, de Assumpção et al. 2016, Frei et al. 2005, and Dencker et al. 2006 showed no statistically significant difference between both genders in the predictive equations [11-13, 8]. While Amra et al. 2007 found a statistically significant difference between genders [10]. But in our study, no significant difference was found between boys and girls regarding IOS parameters except for $\mathrm{R} 20 \mathrm{~Hz}, \mathrm{X} 5 \mathrm{~Hz}$, and $\mathrm{Z} 5 \mathrm{~Hz}$.

Comparing our study on the pediatric age group with other studies in adults, Kalchiem-Dekel and Stella E. Hines studied forty years of reference values for respiratory system impedance in adults from the years 1977-2017 and concluded that most of the prediction equations were from Europe $(n=20)$ and 
Table 6 Summary of the predictive equation of impulse oscillometry in different ethnicities

\begin{tabular}{|c|c|c|c|c|}
\hline Author, year & Ethnicity & Predictive equation & $R^{2}$ & Predictive variables \\
\hline \multirow[t]{14}{*}{ de Assumpção et al. 2016} & Brazilian & Boys & & Height and age \\
\hline & & R5 Hz $=1.699-(0.008 \times$ height $)$ & 62 & \\
\hline & & $\mathrm{R} 20 \mathrm{~Hz}=1.226-(0.005 \times$ height $)$ & 49 & \\
\hline & & $\mathrm{X} 5 \mathrm{~Hz}=-0.552+(0.003 \times$ height $)$ & 15.9 & \\
\hline & & $\mathrm{Z} 5 \mathrm{~Hz}=1.802-(0.010 \times$ height $)$ & 51 & \\
\hline & & Fres $\mathrm{Hz}=44.473-(0.195 \times$ height $)$ & 50.5 & \\
\hline & & $\log A X=0.332-(0.002 \times$ height $)$ & 58 & \\
\hline & & Girls & & \\
\hline & & $\log \mathrm{R} 5 \mathrm{~Hz}=0.639-(0.006 \times$ height $)$ & 57.5 & \\
\hline & & Log R20 Hz = $0.378-(0.005 \times$ height $)$ & 59.1 & \\
\hline & & $\mathrm{X} 5 \mathrm{~Hz}=-0.586+(0.003 \times$ height $)$ & 55.1 & \\
\hline & & $\log Z 5 \mathrm{~Hz}=0.679-(0.007 \times$ height $)$ & 59.9 & \\
\hline & & Log Fres = $1.555-(0.037 \times$ age $)$ & 41.1 & \\
\hline & & $\log A X=0.892-(0.106 \times$ age $)$ & 49.7 & \\
\hline \multirow[t]{6}{*}{ Park et al. 2011} & Korean & Boys & & Boys \\
\hline & & $\mathrm{R} 5 \mathrm{~Hz}=1.934-0.009 \times$ Height & 12.1 & Height and age \\
\hline & & X5 Hz $=0.774+0.006 \times$ Height $-0.002 \times$ Age & 20.2 & \\
\hline & & Girls & & Girls \\
\hline & & $\mathrm{R} 5 \mathrm{~Hz}=2.201-0.012 \times$ Height & 18.2 & Height only \\
\hline & & $X 5 \mathrm{~Hz}=-0.674+0.004 \times$ Height & 10.5 & \\
\hline \multirow[t]{5}{*}{ Denker et al. 2006} & Finland and Sweden & $\mathrm{Z} 5 \mathrm{~Hz}=0.282+0.801 \times$ height $^{-3}+0.004 \times$ weight & & height $^{-3}$ and weight \\
\hline & & $\mathrm{R} 5 \mathrm{~Hz}=0.266+0.759 \times$ height $^{-3}+0.004 \times$ weight & & \\
\hline & & $\mathrm{R} 20 \mathrm{~Hz}=0.259+0.630$ height $^{-3}$ & & \\
\hline & & $\mathrm{X}_{5} \mathrm{~Hz}=-0.123-0.225$ height $^{-3}$ & & \\
\hline & & Fres $=11.749+4.373 \times$ height $^{-3}+0.103 \times$ weight & & \\
\hline \multirow[t]{8}{*}{ Gochicoa-Rangel et al. 2015} & Mexican & $\mathrm{Z} 5 \mathrm{~Hz}=-0.595 \times \log$ age $+130.320 \times$ & & Height and age \\
\hline & & $1 /$ height +0.214 & & \\
\hline & & $\mathrm{R} 5 \mathrm{~Hz}=-0.736 \times \log$ age $+78.861 \times 1 /$ height +0.702 & & \\
\hline & & $\mathrm{R} 20 \mathrm{~Hz}=-0.427 \times \log$ age $+69.880 \times 1 /$ height +0.307 & & \\
\hline & & $X 5 \mathrm{~Hz}=0.309 \times \log$ age $-42.906 \times 1 /$ height -0.185 & & \\
\hline & & Fres $=-0.308 \times \log$ age $+2542.196 \times$ & & \\
\hline & & 1/height +0.791 & & \\
\hline & & $A X=-2.345 \times \log$ age $+640.548 \times 1 /$ height -1.212 & & \\
\hline \multirow[t]{10}{*}{ Amra et al. 2007} & Iranian & Boys & & Height and age \\
\hline & & $\mathrm{R} 5 \mathrm{~Hz}=-6.19 \times 10(-7) \times$ age $\times 3.820-$ & & \\
\hline & & $6.78 \mathrm{E}-005 \times$ height $\times 1.651+0.691$ & & \\
\hline & & X5 Hz $=6.95 \times 10(-23) \times$ age $\times 16.226+$ & & \\
\hline & & 0.004 height $\times 0.846-0.430$ & & \\
\hline & & Girls & & \\
\hline & & $\mathrm{R} 5 \mathrm{~Hz}=-1.35 \times 10(-5) \times$ age $\times 2.823-$ & & \\
\hline & & $0.001 \times$ height $\times 1.022+0.547$ & & \\
\hline & & $\mathrm{X} 5 \mathrm{~Hz}=1.78 \times 10-7) \times$ age $\times 1.08+0.002$ & & \\
\hline & & height $\times 4.150-0.539$ & & \\
\hline Meraz et al. 2007 & Anglo and Hispanic & $\mathrm{R} 5 \mathrm{~Hz}=1.428-0.006 \times$ height & 0.647 & Height \\
\hline
\end{tabular}


Table 6 Summary of the predictive equation of impulse oscillometry in different ethnicities (Continued)

\begin{tabular}{|c|c|c|c|c|}
\hline Author, year & Ethnicity & Predictive equation & $R^{2}$ & Predictive variables \\
\hline & & $\mathrm{R} 20 \mathrm{~Hz}=1.072-0.005 \times$ height & 0.473 & \\
\hline & & $X 5 \mathrm{~Hz}=-0.340+0.001 \times$ height & 0.151 & \\
\hline & & Fres $=27.589-0.008 \times$ height & 0.165 & \\
\hline & & $A X=1.213-0.005 \times$ height & 0.241 & \\
\hline \multirow[t]{4}{*}{ Lai et al. 2015} & Taiwanese & R5 $\mathrm{Hz}=2.4395-0.0134 \times$ height & & Height \\
\hline & & $\mathrm{R} 20 \mathrm{~Hz}=1.3888-0.0069 \times$ height & & \\
\hline & & $X 5 \mathrm{~Hz}=-0.6408+0.0036 \times$ height & & \\
\hline & & $A X=10.4286-0.0686 \times$ height & & \\
\hline \multirow[t]{4}{*}{ Frei et al. 2005} & North American & R5 Hz $=2.11679-0.0099 \times$ height & 0.435 & Height \\
\hline & & $\mathrm{R} 20 \mathrm{~Hz}=1.45644-0.0065 \times$ height & 0.321 & \\
\hline & & $X 5 \mathrm{~Hz}=-1.1974+0.00673 \times$ height & 0.219 & \\
\hline & & $\mathrm{AX}=10.9448-0.684 \times$ height & 0.351 & \\
\hline
\end{tabular}

$Z 5 \mathrm{~Hz}$ impedance at $5 \mathrm{~Hz}, R 5 \mathrm{~Hz}$ resistance at $5 \mathrm{~Hz}, R 20 \mathrm{~Hz}$ resistance at $20 \mathrm{~Hz}, X 5 \mathrm{~Hz}$ reactance at $5 \mathrm{~Hz}$, Fres resonant frequency, $A X$ area of reactance

Asia $(n=12)$ while studies in Africa are limited; and across publications, height and sex were major contributors to prediction equations. The contribution of weight was more pronounced in obese patients only. The contribution of age was less clear, and the elderly were largely under-represented. Ethnicity likely plays a role but was under-reported in currently available publications $[3,16]$.

The study on adults done by Schulz et al. showed that $\mathrm{R} 5 \mathrm{~Hz}$ was higher in females than males while X5 Hz was higher in males than females. Some of the IOS equations were age-dependent. Also, studies by Aarli et al. and Newbury et al. found that airway resistance is greater in women than in men during adulthood $[17,18]$.

By comparing $R^{2}$ of our study to that in the studies done on different ethnicities, we found that our $R^{2}$ is higher than that in the equations of Korean, Angelo, Hispanic, and North American studies. While it was lower than $R^{2}$ of the Brazilian study except for the predictive equation for X5 Hz for boys where our $R^{2}$ was higher (Tables 5 and 6).

This study has a potential limitation that it did not include the population from different cities in Egypt. Further studies are needed to develop reference equations for parameters of IOS on a wider scale and larger sample sizes that can be applied to all Egyptian children and adolescents in different cities.

\section{Conclusion}

Both height and age affected the regression equation for parameters of impulse oscillometry in Egyptian children.

\section{Abbreviations}

AX: Area of reactance; Fres: Resonant frequency; IOS: Impulse oscillometry; $\mathrm{R} 5 \mathrm{~Hz}$ : Resistance at $5 \mathrm{~Hz} ; \mathrm{R} 20 \mathrm{~Hz}$ : Resistance at $20 \mathrm{~Hz}$; X5Hz: Reactance at $5 \mathrm{~Hz}$; Z5Hz: Impedance at $5 \mathrm{~Hz}$

Acknowledgements

Thanks to the staff of Chest clinic, Children's Hospital, Ain Shams University.
Authors' contributions

SI conceived the presented idea, carried out the impulse oscillometry for the subjects, collected the data, and wrote the manuscript, while AH analyzed the data and developed the equations. Both authors have read and approved the manuscript.

\section{Funding}

This research did not receive any funding.

Availability of data and materials

Data and materials are available upon request.

Ethics approval and consent to participate

Approval of the medical ethical committee of Children's Hospital, Ain Shams University, was taken before the study. The committee's reference number is not available. Written informed consent was obtained from a parent or legal guardian of participants under 16 years old.

Consent for publication

Not applicable

Competing interests

No conflict of interest.

Author details

${ }^{1}$ Pediatric Department, Faculty of Medicine, Ain Shams University, Cairo 11865, Egypt. ${ }^{2}$ Community, Environmental and Occupational Medicine Department, Faculty of Medicine, Ain Shams University, Cairo 11865, Egypt.

Received: 18 August 2020 Accepted: 14 October 2020

Published online: 04 November 2020

\section{References}

1. Stanojevic S, Stocks J, Hankinson J, Coates A, Pan H, Rosenthal M (2008) et al, Reference ranges for spirometry across all ages: a new approach. Am J Respir Crit Care Med 177:253-260

2. Lai SH, Yao TC, Liao SL, Tsai MH, Hua MC, Yeh KW, Huang JL (2015) Reference value of impulse oscillometry in taiwanese preschool children. Pediatr Neonatol 56(3):165-170. https://doi.org/10.1016/j.pedneo.2014.09.002 Epub 2014 Nov 8

3. Schulz H, Flexeder C, Behr J, Heier M, Holle R, Huber RM, Jörres RA, Nowak D, Peters A, Wichmann HE, Heinrich J, Karrasch S (2013) Reference values of impulse Oscillometric lung function indices in adults of advanced age. PLoS One 8(5):e63366

4. Kand D, Agrawal A (2016) Impulse oscillometry: the state-of-art for lung function testing. Lung India 33(4):410-416 
5. Park JH, Yoon JW, Shin YH, Jee HM, Wee YS, Chang SJ, Sim JH, Yum HY, Han MY (2011) Reference values for respiratory system impedance using impulse oscillometry in healthy preschool children. Korean J Pediatr (2):64-68

6. Bickel S, Popler J, Lesnick B, Eid N (2014) Impulse Oscillometry interpretation and practical applications. Chest 146(3):841-847

7. Beydon N, Davis SD, Lombardi E, Allen JL, Arets HG, Aurora P et al (2007) An official American Thoracic Society/European Respiratory Society statement: pulmonary function testing in preschool children. Am J Respir Crit Care Med 175:1304-1345

8. de Assumpção MS, Gonçalves RM, Martins R, Bobbio TG, Schivinski Cl (2016) Reference equations for impulse Oscillometry system parameters in healthy Brazilian children and adolescents. Respir Care 61(8):1090-1099

9. Gochicoa-Rangel L, Torre-Bouscoulet L, Martínez-Briseño D, Rodríguez-Moreno L, Cantú González G, Vargas MH (2015) Values of impulse oscillometry in healthy mexican children and adolescents. Respir Care 60(1):119-112

10. Amra B, Soltaninejad F, Golshan M (2007) Respiratory resistance by impulse oscillometry in healthy Iranian children aged 5-19. Iran J Allergy Asthma Immunol 7(1):25-29

11. Frei J, Jutla J, Kramer G, Hatzakis GE, Ducharme FM, Davis GM (2005) Impulse oscillometry: reference values in children 100 to $150 \mathrm{~cm}$ in height and 3 to 10 years of age. Chest 128(3):1266-1273

12. Dencker M, Malmberg LP, Valind S, Thorsson O, Karlsson MK, Pelkonen A, Pohjanpalo A, Haahtela T, Turpeinen M, Wollmer P (2006) Reference values for respiratory system impedance by using impulse oscillometry in children aged 2-11 years. Clin Physiol Funct Imaging 26(4):247-250

13. Meraz EG, Nazeran H, Edalatpour R, Rodriguez C, Montano K, Aguilar C, Avila N, Vidaña JO, Portillo AL (2016) Reference equations for impulse oscillometric and respiratory system model parameters in anglo and hispanic children. Revista Mexicana de Ingeniería Biomédica 38:1

14. Isabel Santos Schivinski C, Seabra de Assumpcão M, Maba Gonçalves R, Martins R, Godoy BT (2015) Reference equations for impulse oscillometry system parameters in Brazilian healthy children and adolescents. Physiotherapy 101(1):eS633-eS832

15. Nowowiejska B, Tomalak W, Radliński J, Siergiejko G, Latawiec W, Kaczmarski M (2008) Transient reference values for impulse oscillometry for children aged 3-18 years. Pediatr Pulmonol 43:1 193-1197

16. Kalchiem-Dekel O, Hines SE (2018) Forty years of reference values for respiratory system impedance in adults: 1977-2017. Respir Med 136:37-47

17. Newbury W, Crockett A, Newbury J (2008) A pilot study to evaluate Australian predictive equations for the impulse oscillometry system. Respirology 13(7): 1070-1075

18. Aarli BB, Eagan TM, Ellingsen I, Bakke PS, Hardie JA (2013) Reference values for within-breath pulmonary impedance parameters in asymptomatic elderly. Clin Respir J 7(3):245-252

\section{Publisher's Note}

Springer Nature remains neutral with regard to jurisdictional claims in published maps and institutional affiliations.

\section{Submit your manuscript to a SpringerOpen ${ }^{\circ}$ journal and benefit from:}

- Convenient online submission

- Rigorous peer review

- Open access: articles freely available online

- High visibility within the field

- Retaining the copyright to your article

Submit your next manuscript at $\boldsymbol{\nabla}$ springeropen.com 